\title{
WSPIERANIE ROZWOJU DZIAEALNOŚCI GOSPODARCZEJ W UJĘCIU ZASAD I WARTOŚCI
}

\section{POLITYKA PAŃSTWA NA RZECZ ROZWOJU DZIAŁALNOŚCI GOSPODARCZEJ}

6 marca 2018 r. uchwalono pakiet ustaw dotyczacy szeroko ujmowanej „przedsiębiorczości”, określany w strategicznych dokumentach rządowych z zakresu rozwoju ${ }^{1}$ jako „Konstytucja Biznesu”. Przyjęte ustawy: Prawo przedsiębiorców ${ }^{2}$, o Centralnej Ewidencji i Informacji o Działalności Gospodarczej i Punkcie Informacji dla Przedsiębiorcy ${ }^{3}$, o Rzeczniku Małych i Średnich Przedsiębiorcó $\mathrm{w}^{4}$ oraz ustawa o zasadach uczestnictwa przedsiębiorców zagranicznych i innych osób zagranicznych w obrocie gospodarczym na terytorium $\mathrm{RP}^{5}$, zastępuja regulację stanowiąca przedmiot normowania ustawy z 2 lipca 2004 r. o swobodzie działalności gospodarczej6.

Można postawić pytanie, czy uprawnione jest, i z jakich powodów, określanie pakietu wskazanych ustaw obejmujących regulacją normatywną prowadzenie działalności gospodarczej w Polsce mianem „Konstytucji Biznesu”, a podstawowe w tym zakresie Pr.przeds. traktować należy jako konstytucję dla przedsiębiorców. Co przesądza o randze tych ustaw, w szczególności zaś Pr.przeds.?

Wobec tak postawionych problemów, a w szczególności podkreślanej nowej jakości przepisów normujących rolę państwa w stosunkach gospodarczych ${ }^{7}$,

\footnotetext{
${ }^{1} \mathrm{Na}$ temat strategicznego programowania w polityce rozwoju zob.: K. Kokocińska, Prawny mechanizm prowadzenia polityki rozwoju $w$ zdecentralizowanych strukturach władzy publicznej, Poznań 2014, s. 309; eadem, Wybrane formy prowadzenia polityki rozwoju, w: B. Popowska, K. Kokocińska (red.), Instrumenty i formy prawne dziatania administracji gospodarczej, Poznań 2009, s. $135-180$.

${ }^{2}$ Dz. U. 2018, poz. 646 (dalej jako: Pr.przeds.).

${ }^{3}$ Dz. U. 2018, poz. 647.

${ }^{4}$ Dz. U. 2018, poz. 648.

${ }^{5}$ Dz. U. 2018, poz. 649. Na temat oceny uchwalania odrębnej (choć w istocie niewprowadzającej istotnych zmian statusu podmiotów zagranicznych) regulacji normatywnej, skutkującej budowaniem odrębnego reżimu prawnego dla aktywności gospodarczej podmiotów zagranicznych i zakresu swobody ich aktywności w tym obszarze, zob.: K. Kokocińska, Prawne aspekty prowadzenia działalności gospodarczej w kontekście wielokulturowości społeczeństw, w: A.J. Szwarc (red.), Panorama prawnych aspektów wielokulturowości społeczeństwa, Poznań 2017, s. 167-178.

${ }^{6}$ T.jedn.: Dz. U. 2017, poz. 2168 ze zm. (dalej jako: u.s.d.g.).

${ }^{7} \mathrm{Z}$ uzasadnienia do ustawy - Prawo przedsiębiorców, druk sejmowy 2051.
} 
konieczne jest ustalenie, a następnie zbadanie podstaw (w tym podstaw konstytucyjnoprawnych) przyjętych konstrukcji prawnych.

Kluczowe znaczenie odgrywają formułowane na poziomie unijnym, a także krajowym cele o charakterze zarówno ekonomicznym, jak i poza ekonomicznym, tworzace koncepcję obowiązującego porządku gospodarczego ${ }^{8}$. Cele te, stanowiące rezultat przyjętej polityki i wynikających z niej kierunków działań, determinowane sa aktualnymi uwarunkowaniami społecznymi, gospodarczymi i przestrzennymi. Ich wyrazem sa przyjmowane strategie rozwoju ${ }^{9}$.

Polityka, traktowana jako wartościowanie i ustalanie kryteriów potrzeb społecznych w obszarze określonych stosunków objętych działalnością organów władzy publicznej, znajduje ostatecznie bezpośrednie odniesienie w aktach prawodawczych ${ }^{10}$. Wpływa ona na wartości ujęte w normach prawnych ${ }^{11}$. $\mathrm{Z}$ tego powodu analizę obowiąującego porządku normatywnego (w kontekście celów i wartości) należy uzupełniać badaniami nad polityką państwa ${ }^{12}$ (i Unii Europejskiej ${ }^{13}$ ), która rozstrzyga o kluczowych obszarach systemu społeczno-gospodarczego ${ }^{14}$.

${ }^{8}$ Zob. K. Kokocińska, Wpływ traktatowych rozwiazań Unii Europejskiej na organizacje procesów gospodarczych w Polsce (w kontekście zasady społecznej gospodarki rynkowej), w: E. Małuszyńska, G. Mazur, P. Idczak (red.), Unia Europejska wobec wyzwań przyszłości. Aspekty prawne, finansowe $i$ handlowe, Poznań 2015, s. 36-46 i cytowana tam literatura.

9 „EUROPA 2020 strategia na rzecz inteligentnego i zrównoważonego rozwoju sprzyjającego włączeniu społecznemu". U podstaw tej strategii leżą trzy priorytety: rozwój inteligentny, rozwój zrównoważony i rozwój sprzyjający włączeniu społecznemu. Sa one ze sobą powiązane i stanowią obraz europejskiej społecznej gospodarki rynkowej w XXI w. Wskazane w niej cele, jak wskazuje strategia, sa istotne i reprezentatywne dla wszystkich państw członkowskich; mają poprawić spójność i solidarność gospodarczą, społeczną i terytorialną. Komunikat Komisji EUROPA 2020 Strategia na rzecz inteligentnego i zrównoważonego rozwoju sprzyjającego włączeniu społecznemu, Bruksela, 3 marca 2010, $\operatorname{KOM}(2010) 2020$ wersja ostateczna.

${ }^{10} \mathrm{~K}$. Kokocińska, Istota aktów programowania rozwoju jako instrumentów oddziatywania państwa na gospodarkę, w: A. Jurkowska-Gomułka (red.), Administracja a strategie i polityki publiczne, Warszawa 2016, s. 25-37.

${ }^{11}$ Eadem, Społeczna gospodarka rynkowa - komplementarność, równowaga czy przewaga wartości? Uwagi na tle działań państwa w zakresie prowadzenia polityki rozwoju, „Gdańskie Studia Prawnicze" 37, 2017, s. 27-36.

${ }^{12}$ Polityka jako przedmiot badań jest wśród nauk administracyjnych domeną nauki polityki administracyjnej, zajmującej się optymalizacją skuteczności działalności publicznej, czyli jej sprawnościa, za: H. Izdebski, M. Kulesza, Administracja publiczna. Zagadnienia ogólne, wyd. 3 rozszerzone, Warszawa 2004, s. 351. J. Jeżewski podkreśla, że treścią polityki administracyjnej jest wskazanie najbardziej przydatnej metody regulacji prawnej w określonej dziedzinie, a także „określenie najbardziej efektywnych, prawem dopuszczonych sposobów działania administracji w osiagnięciu celów publicznych - idem, Polityka administracyjna. Zagadnienia podstawowe, w: A. Błaś, J. Boć (red.), J. Jeżewski, Administracja publiczna, Wrocław 2003, s. 309; zob. także: G. Rydlewski, Polityka $i$ administracja w rzqdach państw członkowskich Unii Europejskiej, Warszawa 2006; P.J. Suwaj, R. Szczepankowski, Wokót pojęcia polityki publicznej, w: B. Kudrycka, B.G. Peters, P.J. Suwaj (red.), Nauka administracji, Warszawa 2009, s. 305; ibidem: P.J. Suwaj, Polityka publiczna jako instrument administrowania.

${ }_{13}$ D.M. Trubek, P. Corttel, M. Nance, „Soft law”, ,hard law” and EU integration, w: J. Scott, G. de Burca, New Governance and Constitutionalism, Oxford 2005, s. 65 i n.

${ }^{14}$ M. Kulesza podkreśla związek polityki z prawem, wskazując, że „[...] istota polityki administracyjnej polega przede wszystkim na ustaleniu najbardziej $\mathrm{w}$ danej dziedzinie przydatnych (skutecznych) metod regulacji prawnej i określeniu najefektywniejszych sposobów działania ad- 
Obecnie cele polityki państwa, których osiagnięcie jest konieczne z punktu widzenia założeń rozwoju kraju, zostały określone w średniookresowej strategii rozwoju kraju - Strategii na rzecz Odpowiedzialnego Rozwoju ${ }^{15}$. Strategia ta zakłada, że zmiany ustawodawcze stanowić mają jeden z podstawowych elementów przebudowy i reformy instytucjonalnej otoczenia przedsiębiorców. Wskazuje się na potrzebę zwiększenia odpowiedzialności instytucji państwa za kształtowanie procesów gospodarczych, społecznych i terytorialnych przy zachowaniu konstytucyjnego modelu społecznej gospodarki rynkowej. Podkreśla się ich aktywność w kreowaniu warunków do rozwoju, co zgodnie ze strategią oznacza podejmowanie działań służących wspieraniu wzrostu gospodarczego $^{16}$. Pakiet analizowanych ustaw określany jest w tej kluczowej strategii ${ }^{17}$ Pakietem Konstytucji Biznesu jako „[...] nowy, spójny pakiet aktów prawnych całościowo regulujących zasady prowadzenia działalności gospodarczej w Polsce, który tworząc korzystne, przejrzyste i stabilne warunki do prowadzenia działalności gospodarczej, zapewnia pewność prawa, zmniejsza ryzyko biznesowe i zwiększa chęć przedsiębiorców do ponoszenia ryzyka technologicznego związanego z realizacją innowacyjnych projektów"; uznany został jednocześnie przez polski rząd za projekt strategiczny ${ }^{18}$.

Wobec tak sformułowanej polityki państwa ${ }^{19}$ oddziaływania na procesy związane z rozwojem gospodarki, w tym z rozwojem działalności gospodarczej, istotna jest ostatecznie przyjęta koncepcja legislacyjna oraz zakres uregulowań realizujących założenia polityki rozwoju społeczno-gospodarczego państwa. Takie ujęcie uzasadnia analizę Pr.przeds. z punktu widzenia celów polityki państwa, której wyrazem są m.in. wartości i zasady przyjęte w aktach normatywnych.

$$
* * *
$$

Podkreślany szczególny charakter Prawa przedsiębiorców wynika z konstrukcji tej ustawy i jej stosunku do pozostałych unormowań pakietu. W pierwszej kolejności zwraca uwagę jej tytuł. Określenie „prawo” zawarte w tytule ustawy jest zastrzeżone dla takich ustaw, które mają charakter podstawowy dla danej dziedziny spraw ( $§ 9$ Zasad techniki prawodawczej ${ }^{20}$ ) lub też są usta-

ministracji, sposobów dopuszczalnych w istniejących uwarunkowaniach prawnych. Chodzi zatem o optymalne ujęcie prawnego wyrazu polityki państwa" - idem, Z problematyki badań nad metodami działania administracji, w: Z. Rybicki, M. Gromadzka-Grzegorzewska, M. Wyrzykowski (red.), Zbiór studiów z zakresu nauk administracyjnych, Ossolineum 1978, s 337.

15 Uchwała numer 8 Rady Ministrów z 14 lutego 2017 r. w sprawie przyjęcia Strategii na rzecz Odpowiedzialnego Rozwoju do roku 2020 (z perspektywą do 2030 r.) (dalej jako: SOR).

16 SOR, s. 35 i n.

17 K. Kokocińska, Instrumenty i prawne formy..., s. 151 i n.

18 SOR, s. 225.

19 J. Jeżewski podkreśla, że treścią polityki administracyjnej jest wskazanie najbardziej przydatnej metody regulacji prawnej w określonej dziedzinie, a także „określenie najbardziej efektywnych, prawem dopuszczonych sposobów działania administracji w osiagnięciu celów publicznych - idem, op. cit., s. 309.

20 Rozporządzenie Prezesa Rady Ministrów z 20 czerwca 2002 r. w sprawie „Zasad techniki prawodawczej”, Dz. U. 2002, Nr 100, poz. 908. 
wami wyczerpująco regulującymi obszerną dziedzinę spraw (§ 19 pkt 2 Zasad techniki prawodawczej). Analizując przedmiot normowania Pr.przeds., należy stwierdzić, że zakres jego regulacji odpowiada wskazanym warunkom, odnosi się bowiem do takich dziedzin, jak: podejmowanie, wykonywanie i zakończenie działalności gospodarczej na terytorium RP, w tym praw i obowiązków przedsiębiorców oraz zadań organów władzy publicznej w tym zakresie. Oznacza to, że Pr.przeds. spełnia rolę aktu prawnego o charakterze podstawowym, a jednocześnie uniwersalnym w obszarze „działalności gospodarczej”, odnosząc się do jej zasadniczych aspektów.

Prawo przedsiębiorców zawiera preambułę, w której wskazano podstawowe wartości, w tym wolność działalności gospodarczej i inne zasady konstytucyjne mające znaczenie dla przedsiębiorców i ich działalności gospodarczej, w szczególności zaś wyprowadzane z zasady demokratycznego państwa prawnego (praworządność, pewność prawa, niedyskryminacja, zrównoważony rozwój) ochrona konkurencji oraz rozwój gospodarki. Przyjęte rozwiązanie, polegajace na umieszczeniu w preambule aktu normatywnego katalogu wartości, odpowiada formułowanemu w doktrynie postulatowi uzasadnienia aksjologicznego norm prawnych ${ }^{21}$, czyli „sytuacj[i], w której argumentuje się, że daną normę należy uznawać za wiążąca, gdyż to, co dana norma nakazuje, jest godne aprobaty, a to, czego zakazuje - godne dezaprobaty" ${ }^{22}$. Normy prawne powinny być osadzone w wartościach ${ }^{23}$.

Szczególny przedmiot odniesienia regulacji normatywnych publicznego prawa gospodarczego, jakim jest gospodarka z wszystkimi jej uwarunkowaniami ${ }^{24}$, znajduje swój wyraz także w przyjętym systemie wartości ${ }^{25}$. Sa to wartości wyznaczone dla stosunków zachodzących pomiędzy państwem (administracja) a gospodarką. System ten tworzą zarówno wartości o charakterze

${ }^{21}$ Zob. J. Zimmermann (red.), Wartości $w$ prawie administracyjnym, Warszawa 2015; idem, Aksjomaty prawa administracyjnego, Warszawa 2013.

${ }^{22}$ Idem, Aksjomaty..., s. 74.

${ }^{23} \mathrm{Na}$ ten temat szerzej praca zbiorowa: M. Zdyb, E. Kruk, G. Lubeńczuk (red.), Dysfunkcje publicznego prawa gospodarczego, Warszawa 2018.

${ }_{24}$ Zob. zbiór artykułów na temat prawa gospodarczego: Co to jest prawo gospodarcze? opublikowanych w „Ruchu Prawniczym, Ekonomicznym i Socjologicznym” 55, 1993, z. 1; a także T. Rabska, Działania administracji publicznej w świetle wspótczesnej koncepcji publicznego prawa gospodarczego, w: B. Popowska, K. Kokocińska (red.), op. cit., s. 16 i n.; K. Strzyczkowski, Uwagi o zadaniach nauki o prawnych formach dziatania administracji gospodarczej, w: ibidem, s. 35 i n.; K. Kiczka, Konstytucjonalizacja publicznego prawa gospodarczego, w: L. Kieres (red.), Nowe problemy badawcze $w$ teorii publicznego prawa gospodarczego (z uwzględnieniem samorzadu terytorialnego), Wrocław 2010, s. 121; L. Kieres, Kierunki rozwoju regulacji publicznego prawa gospodarczego, w: J. Grabowski, K. Pokryszka, A. Hołody-Wydrzyńska, 25 lat fundamentów wolności działalności gospodarczej. Tendencje rozwojowe, Katowice 2013, s. 330; K. Strzyczkowski, Prawo gospodarcze publiczne, wyd. 6, Warszawa 2013, s. 51; J. Grabowski, Kryteria wyodrębnienia, przedmiot $i$ zakres publicznego prawa gospodarczego, w: System prawa administracyjnego, red. R. Hauser, Z. Niewiadomski, A. Wróbel, t. 8A: Publiczne prawo gospodarcze, Warszawa 2013, s. 22 i n. i wskazywana tam literatura.

${ }^{25}$ K. Kokocińska, Funkcjonalność i dysfunkcjonalność przepisów publicznego prawa gospodarczego z perspektywy kryterium wartości (zagadnienia ogólne), w: M. Zdyb, E. Kruk, G. Lubeńczuk (red.), op. cit., s. 25-38. 
uniwersalnym dla całego porządku prawnego: dobro człowieka, sprawiedliwość, moralność, jak i wartości o szczególnym znaczeniu w obszarze regulacji prawa publicznego: legalność, sprawność, celowość działania administracji publicznej ${ }^{26}$. Do katalogu wartości zaliczyć należy także wartości prawnie chronione regulacjami z obszaru publicznego prawa gospodarczego, a wynikające z ustawowo określonych powinności państwa, w tym w szczególności wolności działalności gospodarczej. Łącznie tworzą one system wartości tej dziedziny prawa ${ }^{27}$. Ich odzwierciedlenie stanowi treść preambuły Pr.przeds. Tak skonstruowany system wartości powoduje określone konsekwencje. Instytucje prawne, struktury organizacji, formy działania administracji publicznej nie są obojętne aksjologicznie; powinny uwzględniać element wartościujący ${ }^{28}$. Określone wartości bądź ich zbiory stanowią uzasadnienie wykonywania przez administrację gospodarczą funkcji w społecznej gospodarce rynkowejej, m.in. policji gospodarczej, reglamentacji gospodarczej, regulacji gospodarczej, wspierania gospodarki, które można zrekonstruować na podstawie Pr.przeds.

Przyjęte w danym czasie wartości społeczne, gospodarcze i polityczne, których realizacji oczekuje społeczeństwo ${ }^{30}$, stanowia, o czym mowa była wcześniej, podstawę wyodrębniania zasad - zarówno tych uniwersalnych, jak i zasad szczególnych - zasad publicznego prawa gospodarczego. Rangę Pr.przeds. wyznaczają skodyfikowane w niej zasady, pełniące szczególną rolę w konstrukcji i funkcjonowaniu systemu prawa publicznego gospodarczego. Przy czym chodzi tu o szczególny typ zasad, które określane są jako normy zasady. Doktryna teorii prawa wyróżnia podstawowe kryteria, na podstawie których rozstrzyga się o „zasadniczości” danej normy - uznaniu danej normy za normę - zasadę. Kryteriami tymi są: umiejscowienie normy na określonym szczeblu hierarchii w systemie prawa, relacja normy do innych norm, rola normy wyodrębnionej całości normatywnej oraz uzasadnienie danej normy przez oceny pozaprawne ${ }^{31}$. Odwołując się do elementów treściowych i formalnych

${ }^{26}$ J. Zimmermann, op. cit., s. 78.

${ }^{27}$ K. Kiczka, Wartości w publicznym prawie gospodarczym (zagadnienia wybrane), w: J. Zimmermann (red.), op. cit., s. 250.

${ }_{28}$ Badania w obszarze teoretycznych koncepcji prawnych form działania administracji gospodarczej potwierdzają że odzwierciedla on przyjęty (lub dorozumiany) system wartości. K. Strzyczkowski zaznacza, że w konstrukcji działań administracji publicznej (gospodarczej) tkwią zespoły wartości - idem, Uwagi o zadaniach nauki..., s. 52.

${ }^{29} \mathrm{Na}$ temat funkcji w publicznym prawie gospodarczym zob. opracowanie zbiorowe: B. Popowska (red.), Funkcje współczesnej administracji gospodarczej, Poznań 2006; M. Zdyb, Publiczne prawo gospodarcze, Kraków 1997; C. Kosikowski, Publiczne prawo gospodarcze Polski $i$ Unii Europejskiej, Warszawa 2007; L. Kieres (red.) et al., Administracyjne prawo gospodarcze, Wrocław 2005; K. Strzyczkowski, Prawo gospodarcze...; H. Gronkiewicz-Waltz, M. Wierzbowski (red.), Prawo gospodarcze. Zagadnienia administracyjnoprawne, Warszawa 2017; System prawa..., t. 8A i wskazywana tam literatura; R. Blicharz (red.), Publiczne prawo gospodarcze. Zarys wyktadu, wyd. 1, Warszawa 2015; A. Powałowski (red.), Prawo gospodarcze publiczne, Warszawa 2015.

${ }^{30}$ A. Chełmoński, Zasady publicznego prawa gospodarczego, w: A. Śmieja (red.), Zasady prawa gospodarczego. Materiały konferencyjne, Wrocław 1999, s. 50 i n.

31 Za: M. Kordela, Zasady prawa. Studium teoretycznoprawne, WN UAM, Poznań 2012, s. 14 i cytowana tam literatura. 
w ujmowaniu zasad, postać normy zasady można przypisać nie tylko normom Konstytucji, lecz także normom ustaw. W szczególności normy tego typu kreowane są w kodeksach, pełniących rolę konstytucji dla określonych gałęzi prawa, czy w ustawach regulujących swoim zakresem mniejszy obszar stosunków społeczno-gospodarczych, zapewniając stabilność danej gałęzi (bądź pewnej części) i utrzymanie jej jednolitości ${ }^{32}$. Cechy te spełnia Pr.przeds.

Wyznaczona powyżej perspektywa badawcza, która jest polityka państwa prowadzona na rzecz rozwoju, umożliwić ma dokonanie oceny Pr.przeds. traktowanego jako konstytucja dla przedsiębiorców w kontekście realizacji zadań państwa na rzecz rozwoju działalności gospodarczej. Zamierzeniem badawczym jest udzielenie odpowiedzi na pytanie, czy ustawodawca objął szczególna regulacją prawną zadania organów władzy publicznej w tym obszarze, wskazując prawne instrumenty ich realizacji.

\section{PRZEDMIOT NORMOWANIA PRAWA PRZEDSIĘBIORCÓW}

Ustawa z 6 marca 2018 r. - Prawo przedsiębiorców określa, zgodnie z jej art. 1, zasady podejmowania, wykonywania i zakończenia działalności gospodarczej na terytorium Rzeczypospolitej Polskiej, w tym prawa i obowiązki przedsiębiorców oraz zadania organów władzy publicznej w tym obszarze. Tak określony zakres przedmiotowy ustawy nie stanowi nowego ujęcia legislacyjnego, materia u.s.d.g. było bowiem również podejmowanie, wykonywanie i zakończenie działalności gospodarczej na terytorium RP, a także zadania organów administracji publicznej.

Brzmienie art. 1 Pr.przeds. zbliżone jest do treści przepisu art. 1 u.s.d.g., co świadczy o kontynuacji przyjętej wcześniej koncepcji poszerzenia zakresu unormowań ustaw określających status prawny przedsiębiorców o normy publicznoprawne dotyczące zadań administracji publicznej ${ }^{33}$. Odmienność w przypadku Pr.przeds. widoczna jest w ujęciu przedmiotu regulacji, podkreślającym szczególną rangę praw przedsiębiorców związanych z podejmowaniem i wykonywaniem działalności gospodarczej. Zakresy tych dwóch przedmiotów regulacji ustawowej, tzn. działalności gospodarczej przedsiębiorcy i zadań administracji publicznej, stały się materiami współzależnymi w tym znaczeniu, że aktywność aparatu administracji państwa stanowić ma zapewnienie przedsiębiorcom szerokiego zakresu korzystania z wolności działalności gospodarczej.

32 Ibidem, s. 15.

${ }^{33}$ T. Rabska, Zadania administracji publicznej $w$ działalności gospodarczej (problem zakresu obowiazywania prawa działalności gospodarczej), „Ruch Prawniczy, Ekonomiczny i Socjologiczny” 64, 2002, z. 2, s. 138; także na ten temat: K. Kokocińska, Prawne aspekty wspierania rozwoju przedsiębiorczości - ustawa o swobodzie działalności gospodarczej oraz ustawy ustrojowo-kompetencyjne, „Ruch Prawniczy, Ekonomiczny i Socjologiczny” 67, 2015, z. 4, s. 37. 
Należy przy tym podkreślić, że poprzednie regulacje - zarówno Prawo działalności gospodarczej z 1999 r. ${ }^{34}$, jak i u.s.d.g. z 2004 r. - nie pomijały zagadnień kompetencyjnych organów administracji publicznej w sferze gospodarowania. Różnica tkwi we wskazanym powyżej sposobie ich ujęcia, który wywołuje określone konsekwencje. Dlatego zasadniczą kwestią jest, w jaki sposób podstawowe prawa i wolności, w tym wolność działalności gospodarczej, zostały wypełnione konkretną treścią prawną i jakie działania administracji publicznej, będąc przedmiotem przepisów zarówno Pr.przeds., jak i pozostałych ustaw z pakietu - służą urzeczywistnieniu wolności działalności gospodarczej.

Przyjęta przez ustawodawcę konstrukcja ustawowego określenia zadań organów administracji publicznej zarówno w P.d.g., jak i u.s.d.g. polegała na nadaniu tej materii szczególnej rangi. Wyrazem tego było poświęcenie zadaniom organów administracji publicznej odrębnych przepisów - np. w P.d.g. zagadnieniom tym poświęcony był odrębny rozdz. 8: „Zadania organów administracji rządowej i jednostek samorządu terytorialnego w zakresie działalności gospodarczej”, obejmujący dwie sfery zadań. Pierwsza z nich dotyczyła zadania określonego jako wspieranie działalności gospodarczej, druga sfera obejmowała zadania szczegółowe, kierowane wyłącznie do organów jednostek samorządu terytorialnego. Do katalogu zadań administracji publicznej w działalności gospodarczej ustawodawca P.d.g. wprowadził nowe zadanie (art. 61 tejże ustawy) - wspieranie działalności gospodarczej, wskazując zakres działań administracji ${ }^{35}$. W u.s.d.g. ustawodawca zrezygnował z wyodrębnienia zadań w osobnym rozdziale, określając je przedmiotowo w art. 1 u.s.d.g. jako zadania w zakresie podejmowania, wykonywania i zakończenia działalności gospodarczej, a umiejscowił je w poszczególnych rozdziałach ustawy. Szczególne znaczenie z punktu poruszanej problematyki miał przepis art. 8 u.s.d.g., który wprost odnosił się do zadania ustawowo określonego jako wspieranie przedsiębiorczości ${ }^{36}$.

Przepisy obu tych ustaw poddane zostały krytyce ${ }^{37}$, przede wszystkim ze względu na charakter i sposób ujęcia zadań. Niektórzy przedstawiciele doktryny traktowali te zadania jako programowe ${ }^{38}$ bądź jako niemające szczególnego znaczenia ze względu na ich niewładczy charakter ${ }^{39}$. Bożena Popowska

${ }^{34}$ Ustawa z 19 listopada 1999 r., Dz. U. 1999, Nr 101, poz. 1178 ze zm. (dalej jako: P.d.g.), uchylona na mocy ustawy z 2 lipca 2004 r. Przepisy wprowadzające ustawę o swobodzie działalności gospodarczej, Dz. U. 2004, Nr 173, poz. 1808.

${ }^{35}$ Zadania te koncentrowały się na promowaniu przedsiębiorczości, prowadzeniu działalności informacyjnej i oświatowej, w tym organizowaniu szkoleń w zakresie rozwoju przedsiębiorczości oraz współdziałaniu z samorządem gospodarczym, organizacjami pracodawców i innymi organizacjami przedsiębiorców.

36 Szerzej: K. Kokocińska, Prawne aspekty..., s. 38 i n.; eadem, A. Trela, Wspieranie przedsiębiorczości jako zadanie administracji publicznej, w: P. Wiliński, O. Krajniak, B. Guzik (red.), Prawo wobec wyzwań współczesności, t. 3, Poznań 2006, s. 71-80.

${ }_{37}$ M. Zdyb, Prawo działalności gospodarczej. Komentarz do ustawy z dnia 19 listopada 1999 r., Kraków 2000, s. 708; także: B. Popowska, Wspieranie matych i średnich przedsiębiorców - charakterystyka przepisów Prawa działalności gospodarczej $i$ ich realizacja, „Ruch Prawniczy, Ekonomiczny i Socjologiczny” 64, 2002, z. 2, s. 125 i n.

38 M. Zdyb, op. cit., s. 707.

39 C. Kosikowski, Prawo działalności gospodarczej. Komentarz, Warszawa 2000, s. 142. 
wskazywała, że w art. 61 P.d.g. ustawodawca wymienia przykładowe, kierunkowo ujęte działania, które organy powinny podejmować, o ile mieszczą się w zakresie ich zadań określonych przepisami prawa ustrojowego i prawa materialnego ${ }^{40}$. Teresa Rabska traktowała postanowienia P.d.g. jako wprowadzające obowiązek wspierania działalności gospodarczej przez organy administracji publicznej, wyrażające kierunek wykładni przepisów ustawowych. Przepis prawny tak skonstruowany stanowi normę interpretacyjną dla organów oraz wprowadza nowe zasady ogólne postępowania administracyjnego w zakresie działalności gospodarczej ${ }^{41}$. To ujęcie zasługuje na szczególne podkreślenie z punktu widzenia prowadzonej analizy Pr.przeds.

\section{ROZWÓJ DZIAŁALNOŚCI GOSPODARCZEJ JAKO ZADANIE PAŃSTWA}

Prawo przedsiębiorców nie zawiera, tak jak w poprzednich regulacjach P.d.g. oraz u.s.d.g., wyrażonego ustawowo zobowiązania organów administracji publicznej do prowadzenia działań na rzecz wspierania przedsiębiorczości. W preambule Pr.przeds. w brzmieniu:

Kierując się konstytucyjną zasadą wolności działalności gospodarczej, a także innymi zasadami konstytucyjnymi mającymi znaczenie dla przedsiębiorców i wykonywanej przez nich działalności gospodarczej, w tym zasadami praworządności, pewności prawa, niedyskryminacji oraz zrównoważonego rozwoju,

uznając, że ochrona i wspieranie wolności działalności gospodarczej przyczyniają się do rozwoju gospodarki oraz do wzrostu dobrobytu społecznego,

dążąc do zagwarantowania praw przedsiębiorców oraz uwzględniając potrzebę zapewnienia ciagłego rozwoju działalności gospodarczej w warunkach wolnej konkurencji,

uchwala się, co następuje: [...]

podkreśla się konieczność podejmowania działań ukierunkowanych na rozwój działalności gospodarczej, ustawodawca akcentuje, że państwo powinno zapewnić rozwój działalności w warunkach wolnej konkurencji, kierując się konstytucyjna zasadą wolności gospodarczej oraz innymi zasadami odnoszącymi się do tej sfery aktywności obywateli. Jednocześnie uwypukla znaczenie i potrzebę ochrony oraz wspierania wolności działalności gospodarczej, które to działania przyczyniają się do rozwoju gospodarki oraz do wzrostu dobrobytu społecznego.

Poza preambuła Pr.przeds. nie obejmuje przepisów wprost odnoszących się do działań administracji w obszarze ustawowo wyznaczonym celem, którym jest „rozwój działalności gospodarczej”. Ustawodawca nie rozstrzyga jednoznacznie zakresu normowania w obrębie tej sfery, akcentując, że wszelkie działania organów administracji publicznej objęte regulacją Pr.przeds. powinny być wykonywane z uwzględnieniem zapewnienia ciagłego rozwoju działalności gospodarczej. Ujęcie powyższe wskazuje na bardzo szerokie traktowanie

${ }^{40}$ B. Popowska, op. cit., s. 128.

${ }^{41}$ T. Rabska, Zadania administracji..., s. 146. 
tej sfery oddziaływania administracji na stosunki gospodarcze. Ich wyrazem jest aktywność administracji publicznej wykonującej szczegółowe zadania; przykładowo w procedurze ewidencjonowania działalności gospodarczej ${ }^{42}$, realizacji kompetencji związanych z reglamentacją działalności gospodarczej ${ }^{43}$, koncesjonowaniem czy aktywnością Rzecznika Małych i Średnich Przedsiębiorców ${ }^{44}$. Innym, charakterystycznym i nowym (na tle dotychczasowych uregulowań) typem obowiązków organów administracji publicznej na rzecz rozwoju działalności gospodarczej są obowiązki określonego działania lub zaniechania działań wynikające z przepisów zawierających zasady postępowania organów administracji publicznej w relacjach z przedsiębiorcami ${ }^{45}$.

Podejmując próbę porządkowania zasad prawa przyjętych w Pr.przeds., można je podzielić na te, które kierowane są do przedsiębiorców, i te, które kierowane są do organów władzy publicznej, jako wiążące w ich stosunkach z przedsiębiorcami ${ }^{46}$. Do pierwszej ze wskazanych grup zalicza się zasady: wolności działalności gospodarczej (art. 2 Pr.przeds.): co nie jest prawem zabronione, z zasady jest dozwolone (art. 8 Pr.przeds.), oraz zasadę wynikająca z art. 9 tejże ustawy, a wprowadzająca obowiązek wykonywania działalności gospodarczej zgodnie z zasadami uczciwej konkurencji i poszanowania dobrych obyczajów oraz słusznych interesów innych przedsiębiorców i konsumentów. Druga kategoria obejmuje (poza wskazanymi powyżej) zasady: domniemania uczciwości przedsiębiorcy (art. 10 ust. 1 Pr.przeds.); rozstrzygania wątpliwości faktycznych na korzyść przedsiębiorcy (art. 10 ust. 2 Pr.przeds.); przyjaznej interpretacji przepisów (art. 11 Pr.przeds.); pogłębiania zaufania, proporcjonalności, bezstronności i równego traktowania (art. 12 Pr.przeds.); odpowiedzialności urzędników za naruszenie prawa (art. 13 Pr.przeds.); pewności prawa (art. 14 Pr.przeds.) oraz zasadę udzielania informacji (art. 15 Pr.przeds.).

Zasady te mają wymiar uniwersalny i odnoszą się do wszelkich stosunków związanych z podejmowaniem, wykonywaniem i zakończeniem działalności gospodarczej, podkreślając charakter ustroju gospodarczego państwa. Według Andrzeja Powałowskiego zasady te nawiąują do konstytucyjnej zasady społecznej gospodarki rynkowej, do której to ustrojowej zasady Pr.przeds. (mimo jego znaczenia) nie odwołuje się wprost ${ }^{47}$. Marian Zdyb podkreśla, że zasady przyjęte w Pr.przeds. wskazują fundamenty ładu publicznego, ładu gospodarczego opierającego się na aksjologicznych podstawach, których źródłem jest

${ }^{42}$ Szerzej: A. Trela, Centralna Ewidencja i Informacja o Działalności Gospodarczej w świetle nowych przepisów prawnych w tym zeszycie RPEiS.

${ }^{43}$ Szerzej: M. Strzelbicki, Reglamentacja działalności gospodarczej $w$ świetle ustawy Prawo przedsiębiorców na tle unormowań wcześniejszych w tym zeszycie RPEiS.

${ }^{44} \mathrm{Na}$ ten temat: P. Lissoń, Rzecznik Małych i Średnich Przedsiębiorców: ombudsman czy organ administracji rzqdowej? w tym zeszycie RPEiS.

${ }_{45}$ Szerzej: B. Popowska, Zasady postępowania $w$ sprawach z zakresu działalności gospodarczej unormowane w ustawie Prawo przedsiębiorców w tym zeszycie RPEiS.

${ }^{46}$ Tak np.: M. Sieradzka, Podstawowe zasady obowiazujace przy podejmowaniu wykonywaniu oraz zakończeniu działalności oraz ich wpływ na sytuację prawna przedsiębiorcy, Ustawa z 6.3.2018 r. - Prawo przedsiębiorców - analiza i ocena najważniejszych przepisów, red. M. Sieradzka, dodatek do „Monitora Prawniczego” 2018, nr 13, s. 21.

${ }^{47}$ A. Powałowski, op. cit., s. 129. 
Konstytucja $\mathrm{RP}^{48}$. Oznacza to, że wskazane w nich wartości o istotnym znaczeniu (np. równość, praworządność) powinny być uwzględniane w procesie stanowienia i stosowania prawa. Osadzenie norm prawnych w wartościach wpływa na treść i sposób działania organów władzy publicznej. Jak podkreśla Jan Zimmermann, dzięki przyjętym wartościom podmioty stosujące prawo działają zgodnie ze stałymi założeniami aksjologicznymi ${ }^{49}$.

\section{PRZYKŁADOWE INSTRUMENTY WSPIERANIA ROZWOJU DZIAŁALNOŚCI GOSPODARCZEJ}

Ogólnikowość określonego w Pr.przeds. celu, którym jest wspieranie rozwoju działalności gospodarczej, nie oznacza, że w obrocie gospodarczym nie funkcjonują rozwiązania instytucjonalne służące jego osiagnięciu. Przykładem działań zmierzających do jego realizacji, wpisujących się w politykę państwa na rzecz rozwoju, sa instrumenty wsparcia regulowane przepisami ustawy z 10 maja 2018 r. o wspieraniu nowych inwestycji ${ }^{50}$. Ta nowa ustawa określa zasady udzielania przedsiębiorcom wsparcia na realizację nowych inwestycji, co zgodnie z ustawą (art. 2 pkt 1) oznacza inwestycję w rzeczowe aktywa trwałe lub wartości niematerialne i prawne zwiąane z założeniem nowego przedsiębiorstwa, zwiększeniem zdolności produkcyjnej istniejącego przedsiębiorstwa, dywersyfikacją produkcji przedsiębiorstwa przez wprowadzenie produktów uprzednio nieprodukowanych w przedsiębiorstwie lub zasadniczą zmianą dotyczacca procesu produkcyjnego istniejącego przedsiębiorstwa $^{51}$. Ustawa określa także organ właściwy w sprawach wspierania nowych inwestycji - jest nim minister właściwy do spraw gospodarki - oraz jego kompetencje i tryb działania, a także zadania zarządzających obszarami odpowiedzialnych za wspieranie nowych inwestycji. Wsparcie na realizację nowej inwestycji jest udzielane $\mathrm{w}$ formie zwolnienia od podatku dochodowego, na zasadach określonych odpowiednio w przepisach o podatku dochodowym od osób prawnych albo w przepisach o podatku dochodowym od osób fizycznych, i stanowi pomoc regionalna.

Wspieranie rozwoju działalności gospodarczej nie jest zadaniem nowym, poza ogólnymi przepisami P.d.g. i u.s.d.g. obowiązywały bowiem (i obowiązuja) regulacje szczegółowe w tym zakresie, w tym ustawa z 20 października 1994 r. o specjalnych strefach ekonomicznych ${ }^{52}$ (ustawa o wspieraniu nowych inwestycji jest z nią bezpośrednio powiązana, gdyż dotyczy zachęt podatkowych dla przedsiębiorców dostępnych na terenie całego kraju, bez ograniczeń

${ }^{48}$ M. Zdyb, Podstawowe zasady (standardy) tadu gospodarczego w świetle ustawy z 6.3.2018 r. Prawo przedsiębiorców, w: Ustawa z 6.3.2018 r..., s. 12.

49 J. Zimmermann, Aksjomaty...

${ }^{50}$ Dz. U. 2018, poz. 115.

${ }^{51} \mathrm{Z}$ wyłączeniem przedsiębiorstwa, wobec którego wszczęte zostało postępowanie upadłościowe lub został złożony wniosek do sądu o ogłoszenie upadłości.

${ }^{52}$ T.jedn.: Dz. U. 2017, poz. 1010 ze zm. 
terytorialnych) czy ustawa o niektórych formach wspierania działalności innowacyjnej z 30 maja 2008 r. ${ }^{53}$ (określająca zasady wspierania działalności innowacyjnej przez udzielanie kredytu technologicznego przez banki kredytujące i premii technologicznej przez Bank Gospodarstwa Krajowego, nadawanie przedsiębiorcy statusu centrum badawczo-rozwojowego oraz pomoc udzielana w ramach programów w obszarze innowacyjności gospodarki, ustanawianych przez ministra właściwego do spraw gospodarki).

Ten typ działań państwa na rzecz rozwoju określany jest w doktrynie publicznego prawa gospodarczego jako wspieranie gospodarki przez państwo ${ }^{54}$. Służy on poprawie prawnej i faktycznej pozycji przedsiębiorców ${ }^{55}$, stwarzając możliwość pełniejszego korzystania z przysługującej im wolności działalności gospodarczej. Stąd wspieranie rozwoju działalności gospodarczej traktować należy jako element wspierania gospodarki analizowanego w dotychczasowym ujęciu. Jednocześnie, co należy szczególnie podkreślić w związku z postawiona na wstępie teza, cele określone w ustawach szczegółowych (w Pr.przeds. jest to ciąły rozwój działalności gospodarczej) stanowią rezultat przyjętej polityki państwa. Dlatego wskazuje się, że realizacja funkcji wspierania gospodarki służy osiaganiu celów polityki państwa przez oddziaływanie na zachowanie przedsiębiorców, którzy politykę tę realizują. „Realizacja tej funkcji polega na wywieraniu w sposób niewiążący wpływu na kształtowanie porządku społeczno-gospodarczego poprzez udzielenie ze środków publicznych pomocy podmiotom prywatnym, co nierzadko związane jest dodatkowo z zobowiązaniem do postępowania zgodnie z uprzednio ustalonymi warunkami, w interesie publicznym" 56 . Państwo, stwarzając warunki do rozwoju działalności gospodarczej, stosuje instrumenty zachęcające przedsiębiorców do określonych, pożądanych przez państwo zachowań, realizujących cele polityki rozwoju społeczno-gospodarczego.

\section{PODSUMOWANIE}

Prawo przedsiębiorców, podobnie jak ustawa o swobodzie działalności gospodarczej, obejmuje swoją regulacją prawa i obowiązki przedsiębiorców podejmujących i prowadzących działalność gospodarcza, a także zadania administracji w tym zakresie. Nie wprowadza w tej materii szczególnie istotnych zmian. Prawo przedsiębiorców, podobnie jak pozostałe ustawy pakietu „Konstytucji Biznesu”, ma raczej charakter porządkujacy, uszczegółowiajacy obowiąujace i stosowane dotychczas instytucje prawne (np. w zakresie reglamentacji działalności gospodarczej, jej ewidencjonowania czy prowadzenia kontroli).

\footnotetext{
53 T.jedn.: z 8 grudnia 2017 r., Dz. U. 2018, poz. 141 ze zm.

${ }_{54}$ T. Kocowski, L. Kieres, K. Horubski, Funkcje administracji gospodarczej, w: System prawa..., t. 8a, s. 756 i n. i cytowana tam literatura.

55 K. Strzyczkowski, Prawo gospodarcze publiczne, Warszawa 2011, s. 191.

${ }^{56}$ K. Horubski, Funkcje administracji gospodarczej, w: System prawa..., t. 8A, s. 756.
} 
Zwrócić jednak należy uwagę na sposób ujęcia zakresu normowania Pr.przeds. Materia objęta regulacją tej podstawowej dla stosunków gospodarczych ustawy osadzona została w wartościach prawnych o zasadniczym znaczeniu dla przedsiębiorców. Zasada praworządności, pewności prawa, niedyskryminacji oraz zrównoważonego rozwoju, wolność działalności gospodarczej, stanowiące fundament rozwoju gospodarki oraz wzrostu dobrobytu społecznego, służą jednoznacznie określonym celom: zagwarantowaniu praw przedsiębiorców oraz zapewnieniu ciagłego rozwoju działalności gospodarczej w warunkach wolnej konkurencji. Zasady te oraz cele, których osiagnięciu maja służyć (i to zarówno na etapie stosowania, jak i stanowienia prawa), podkreślają status przedsiębiorców, znaczenie gospodarczych wolności i praw podmiotowych.

W uzasadnieniu projektu Pr.przeds. podkreśla się, że zakotwiczenie zasad w ustawie ,[...] stanowi dodatkowe i dobitne przypomnienie organom władzy publicznej, że w ich relacjach z przedsiębiorcami zasady te mają pełną moc wiążącą i muszą być bezwzględnie przestrzegane, gdyż nie są one jedynie normami programowymi Konstytucji RP lub niewiążącymi apelami. Zasady te sa normami prawnymi par excellence i muszą być przez organy władzy publicznej respektowane tak samo jak wszystkie pozostałe normy prawne zawarte w ustawie $[. . .]^{\prime 57}$. Tym samym ustawodawca podkreśla pozycję przedsiębiorcy i przysługujące mu prawa także $\mathrm{w}$ stosunkach z administracją publiczna.

Analiza przepisów ustawy w kontekście realizacji celu określonego przez ustawodawcę jako „ciąły rozwój działalności gospodarczej” prowadzi do wniosku, że to ustawowe określenie zachowań administracji publicznej mieści się w znanej i opisanej w doktrynie kategorii prawnej, którą jest „wspieranie przedsiębiorczości”. Przy czym są to zarówno szczegółowe zadania organów administracji publicznej związane z realizacja typowych funkcji administracji w działalności gospodarczej, jak i ogólne normy postępowania w stosunkach z przedsiębiorcami.

dr hab. Katarzyna Kokocińska

Profesor Uniwersytetu im. Adama Mickiewicza w Poznaniu

katarzyna.kokocinska@amu.edu.pl

https://orcid.org/0000-0002-1008-3538

\section{SUPPORTING DEVELOPMENT OF ECONOMIC ACTIVITY \\ IN THE LIGHT OF PRINCIPLES AND VALUES}

Summary

The normative scope of the Act: Law on Entrepreneurs encompasses the rules of the undertaking, performance and termination of economic activity on the territory of the Republic of Poland, including the rights and the obligations of entrepreneurs as well as the tasks of public authority. Although the subject matter of the Act does not differ substantially from what was regulated by the Act on Freedom of Economic Activity, attention should be drawn to the manner in which the normative scope of the law on entrepreneurs is approached. The subject matter

${ }^{57} \mathrm{Z}$ uzasadnienia do ustawy Prawo przedsiębiorców, druk sejmowy 2051, s. 28. 
which the Act regulates, being a fundamental law governing economic relationships, has been anchored in legal values whose significance for entrepreneurs is nothing short of crucial, while the principles it relies on (the rule of law, legal certainty, freedom of economic activity) serve specific purposes, in that they seek to ensure the rights of entrepreneurs and guarantee continuous development of economic activity under conditions of free competition. These principles underscore the status of entrepreneurs, the significance of economic liberties and subjective rights. An analysis of the provisions contained in the Act in the light of its objective which the legislator formulates as 'continuous development of economic activity,' leads to the conclusion that this statutory determination of the behaviours of public administration dovetails with the legal category of 'supporting entrepreneurship', a category both acknowledged and described in the doctrine. Significantly enough, the behaviours in question span detailed tasks of public administration which need to be carried out as part of its typical functions within the domain of economic activity, as well as general norms governing the interaction between the administration and the entrepreneurs. 
